\title{
The Effect of Explant Types and Kinetin Concentration on In Vitro Callus Induction in Vetiveria zizanioides (L.) Nash
}

\author{
Arbaul Fauziah, Wahyu Widoretno* \\ Department of Biology, Faculty of Mathematics and Natural Sciences, Indonesia
}

\begin{abstract}
The aims of this research were to evaluate the effect of explant types and several kinetin concentrations on in vitro induction and growth of callus vetiver (Vetiveria zizanioides (L.) Nash). Crown and tiller of vetiver were cultured on Murashige and Skoog's (MS) media supplemented with combination of 2,4-D $0.75 \mathrm{ppm}$ and several kinetin concentrations $(0,0.3,0.5,0.75$, and 1$) \mathrm{ppm}$. The induction and growth of callus were influenced by type of explant and concentration of kinetin. Formation and growth of callus on tiller explant were faster than crown explant. Callus on tiller explant were formed one week after culture, while callus from crown explant were formed at four weeks after culture. Callus growth on tiller explant also was better than crown explant. Eight weeks after culture, callus fresh weight from tiller explant was $0.35 \pm 0.09 \mathrm{~g}$, while callus fresh weight from crown explant was only 0.16 $\pm 0.08 \mathrm{~g}$. The addition of kinetin in the medium combined with 2,4-D was able to increase callus growth and the optimum concentration of kinetin used was $0.5 \mathrm{ppm}$. The addition of kinetin more than $0.5 \mathrm{ppm}$ in the medium decreased the callus fresh weight.
\end{abstract}

Keywords: callus, crown, in vitro culture, tiller, Vetiveria zizanioides.

\section{INTRODUCTION}

Vetiver grass (Vetiveria zizanioides (L.) Nash) is a perennial grass from the family Graminae (Poaceae). It has been utilized as various fields such as industries, economies, and environments [1]. Utilization of vetiver in the various fields is caused by the essential oil contents. The need for essential oils increases along with the development of the medicines, perfumes, cosmetics, and aromatherapy industries. The needs of essential oils in the world, especially vetiver oil is 300 tons per year. However, Indonesia is only able to supply about $28 \%$ with the price of essential oil production of approximately 25-30 tons per year [2]. One of the attempts which can be used to increase the essential oil is cell culture. Cell culture is a technique which can be used to increase the production of bioactive compounds in plants. Through tissue culture, bioactive compounds can be produced continuously, controlled and manipulated environment to obtain optimum results [3].

Increasing bioactive compound through cell culture has been carried out by some methods, one of them is callus culture. Callus culture has increased quinone compound in Peritassa campestris about 2.5 folds [4] and isopenoid in Artemisia annua L. 2.5 folds higher than

\footnotetext{
* Correspondence address:

Wahyu Widoretno

Email : wahyu_widoretno@yahoo.com

Address : Dept. Biology, University of Brawijaya, Veteran Malang, 65145 .
}

compounds produced in vivo [5]. Thus, the attempt to obtain a callus culture method in vetiver is necessary.

Plant growth regulator is one of the factors which can influence the success of callus cell culture. One of the growth regulator has been used to promote callus formation is kinetin. The use of kinetin in callus induction has been done in Andropogon gerardii [6]. In addition, the success of cell culture or callus culture growth is also affected by explant type used. Callus induction has been performed from shoot base explant in Vetiveria zizanioides [7] and tiller explant in Pennisetum purpureum Schum [8]. However, the used of tiller explant in vetiver plants for callus induction has never been done. Therefore, in this research, the callus induction will be performed by tiller explant in vetiver on media supplemented with several kinetin concentrations. The objectives of the current study were to determine the effect of explant type and kinetin concentration on formation and growth of callus in vetiver.

\section{MATERIALS AND METHODS \\ Plant material}

Plants of Vetiveria zizanioides (L.) Nash. were collected from Sengklek, Pamalayan Village, Bayongbong District, Garut, West Java. These plants were washed by using running tap water, then trimmed about $4 \mathrm{~cm}$ from the base of shoot and separated from the root. The trimmed plants were disinfected using $96 \%$ alcohol for a minute, 


\section{(Fauziah et al.)}

sterilized using $80 \%$ commercial whitening agent (containing $5.25 \% \mathrm{NaClO}$ ) for 25 minutes, and finally rinsed by using sterile aquadest twice each for five minutes. Sterile trimmed of plant was cleft, then the crown (part of plant intercourse between tiller and root system) and tiller were used as explant.

\section{Callus Induction}

The crown and tiller explant measured \pm 0.2 $\mathrm{cm}$ from the base were cultured on MS basal medium containing 2,4-D $0.75 \mathrm{ppm}$ and kinetin $(0,0.3,0.5,0.75$, and 1$) \mathrm{ppm}$. The cultures were incubated at room temperature $25-26^{\circ} \mathrm{C}$ with 600 lux light intensity for 8 weeks. Each treatment was repeated three times (three bottles). Each bottle consists of one explant for crown and three explants for tiller. The observation parameters were formation and growth of callus including the time of first callus formation, morphology, and callus fresh weight.

\section{RESULT AND DISCUSSION}

Callus were induced from crown and tiller explant cultured on MS basal media supplemented with 2,4-D alone or combination of 2,4-D and kinetin. Callus started to form from the edge of explant and then followed by the entire of surface explant. These calli tend to be yellow to whitish yellow and transparent in color. Induction and growth of callus in vetiver is affected by explant types and concentration of kinetin in the medium. However, there are not interaction between explant type and kinetin concentration on formation and growth of callus.

The type of explant had significant effect on formation and growth of callus in vetiver. Callus formation from tiller explant were faster than callus formation from crown explant. Callus from tiller explant started to form a week after culture, while callus from crown explant were formed four weeks after culture. In addition of the faster callus formation, the callus growth from tiller explant was also better than crown explant (Fig. 1).

At 8 weeks after culture, the callus fresh weight from tiller explant was $0.35 \pm 0.09 \mathrm{~g}$, while the fresh weight callus from crown explant was only $0.16 \pm 0.08 \mathrm{~g}$ (Fig. 2). It was shown by the distinct difference in callus growth from both of two type of explants, biomass of callus from tiller explant was higher twice than biomass of callus from crown explant.

Addition of $0.3-1 \mathrm{ppm}$ kinetin in combination with $0.75 \mathrm{ppm}$ 2,4-D did not significantly influence the formation and growth of callus.
However, the addition of kinetin in the medium in combination with $0.75 \mathrm{ppm} 2,4-\mathrm{D}$ tended to increase callus growth. On the other hand, when the concentration of kinetin was higher than 0.5 ppm (0.75-1 ppm) callus growth began to decrease. Callus fresh weight on medium containing 2,4-D alone was only $0.17 \pm 0.07 \mathrm{~g}$, while on medium containing $0.75 \mathrm{ppm} 2,4-\mathrm{D}$ in combination with $0.3-1 \mathrm{ppm}$ kinetin was $0.23 \pm$ $0.13-0.28 \pm 0.15 \mathrm{~g}$. The addition of $0.5 \mathrm{ppm}$ kinetin in the medium produced the highest callus fresh weight than the other treatments, it was $0.32 \pm 0.12 \mathrm{~g}$ (Fig. 3 ).
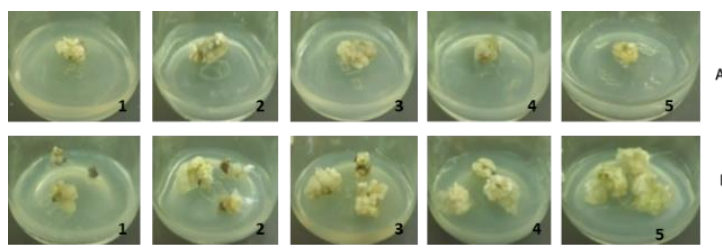

Figure 1. Formation and growth of callus from crown explant (above, A) and tiller explant (bottom, B) on MS basal medium supplemented with combination of 2,4-D $0.75 \mathrm{ppm}$ and several kinetin concentrations.

Description: $A 1$ and $B 1$ without kinetin (control), A2 and B2 kinetin $0.3 \mathrm{ppm}, \mathrm{A} 3$ and $\mathrm{B} 3$ kinetin $0.5 \mathrm{ppm}, \mathrm{A} 4$ and $\mathrm{B} 4$ kinetin $0.75 \mathrm{ppm}$, $\mathrm{A} 5$ and $\mathrm{B} 5$ kinetin $1 \mathrm{ppm}$.

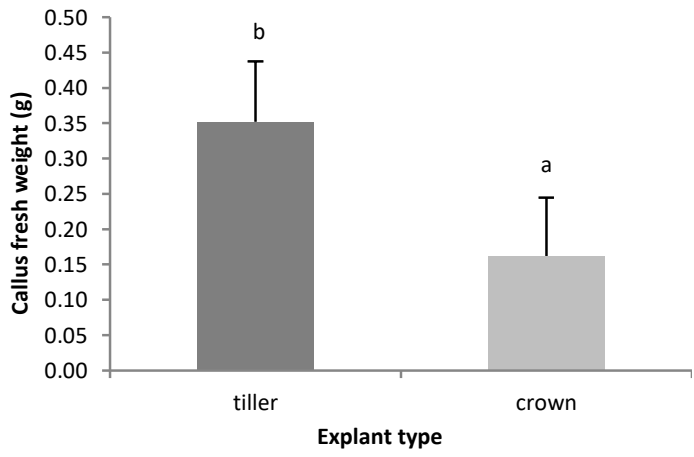

Figure 2. Effect of explant types on vetiver callus fresh weight at 8 weeks after culture.

Note: the same letter of each bar showed no significant on BNT test $(\alpha=0.05)$

Increased fresh weight in medium supplemented with kinetin was quite large, however there was no significant difference in statistical analysis on biomass of callus on medium only containing 2,4-D alone. This is probably due to the very high variation of callus fresh weight on each treatment.

Some factors such as genotype of plant, explant source, basal medium, and growth regulator in the medium affect the formation and growth of callus [9]. Explant has important role on the success of callus initiation. Explant of 
young tissue generally more responsive than the oldest tissue [10]. Explant from meristematic tissue forms the callus faster than dorman tissue [11].

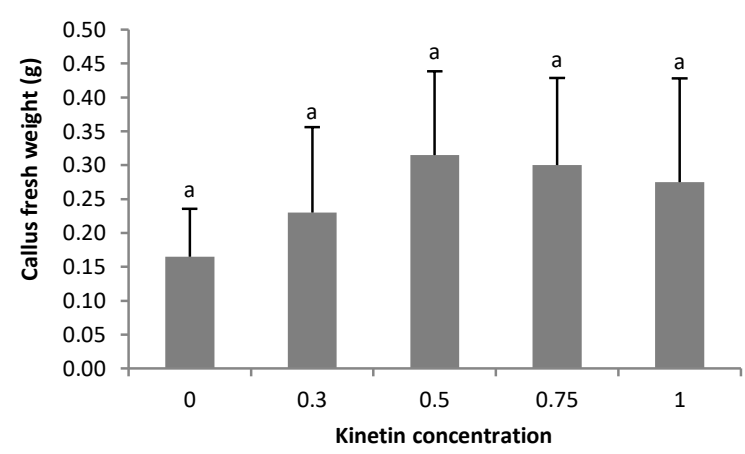

Figure 3. Effect of kinetin concentration in combination with 2,4-D 0.75 ppm on callus fresh weight at 8 weeks after culture.

Note: the same letter of each bar showed no significant on BNT test $(\alpha=0.05)$

In Trigonella foenum Graecum L., the percentage of callus formation from hypocotyl explant was higher than cotyledon explant [12]. In the study [13], the highest percentage of callus formation in Sphenostylis stenocarpa Hochst. was formed from leaf and stem compared with root explant. Nodal explant showed better response on callus induction in Citrus jambhiri that better than leaf and root explant [14]. While the results of research [15], showed that callus growth in Ricinus communis from cotyledon explant was better than root explant.

The difference response of callus formation on each explant were caused by the different physiology condition of each explant. The success of callus formation is increasing with using young tissue as explant source. The tissue that growth actively on earlier of growth period is an excellent explant source, because the ability of the organ division process on the older tissue decreased [16]. According to previous study, the young tissue is generally proliferate easier than old tissue [17].

The success of the callus induction depends on the type and concentration of growth regulator. Callus formation was affected by auxin or combination between auxin and cytokinin. Kinetin is one of growth regulator which often combined with auxin to promote the callus formation [18]. Kinetin promotes the development of cell and affects the development of cell physiology [19]. The addition of kinetin could induce the callus from leaf explant in Talinum paniculatum [20] and shoot tip explant in Shorgum bicolor [21].
Some research results also showed that the callus formation was affected by explant type used and growth regulator in the medium. In Vetiveria zizanioides, the addition of $1 \mathrm{ppm}$ kinetin combination in 2,4-D dan IAA produced callus from shoot base explant $47 \%$ [22], whereas $1 \mathrm{ppm}$ kinetin promoted optimum callus growth $85 \%$ from axillar bud explant with combination in NAA [23]. The result of other research showed that the addition of $0.5 \mathrm{ppm}$ kinetin in the medium in combination with 2,4-D produced callus $32.78 \%$ from leaf disc and $20 \%$ hypocotyl explant in tomato [24]. In addition to the type of explant, growth regulator also as important factor that affected the success of callus induction. On leaf explant in Sauropus androgynous, the addition of $1 \mathrm{ppm}$ kinetin in combination with NAA in the medium resulted callus formation $20 \%$, while the addition of 0.5 ppm kinetin promotes callus formation only $13 \%$ [25]. The addition of kinetin in combination with NAA promotes the callus formation from root explant in Sphenostylis stenocarpa Hochst. On root explant in Sphenostylis stenocarpa Hochst., the addition of $3 \mathrm{ppm}$ kinetin in the medium produce the percentage of callus higher than 1.5 ppm kinetin, respectively 50\% dan $16 \%$ [13].

\section{CONCLUSION}

Formation and growth of callus in vetiver were affected by explant type and kinetin concentration supplemented in the medium. The formation and growth of callus from tiller explant were faster and better than crown explant. In addition, the formation and growth of callus were also affected by kinetin in the medium. The addition of $0.3-1 \mathrm{ppm}$ kinetin in combination with $0.75 \mathrm{ppm} 2,4-\mathrm{D}$ in the medium increased callus growth. However, higher concentration of kinetin, which were 0.75-1 ppm, the callus growth started to decrease.

\section{ACKNOWLEDGEMENT}

The authors would like to thank Ministry of Research, Technology and Higher Education, Republic of Indonesia for financial supports to conduct this research.

\section{REFERENCES}

[1] Cedo, M.L.O, N.L. Ma. Joahna, R.Z. Rocelie, C.C. de Guzman. 2012. Enhanced plantlet regeneration and In Vitro root production in Vetiver (Vetiveria zizanioides (L.) Nash). Philipp. Agric. Scientist. 9(4). 344-351.

[2] Mulyati, H., A. Setiawan, M. Rusli. 2009. Rancang bangun sistem manajemen rantai 
pasokan dan risiko minyak Akar Wangi berbasis IKM di Indonesia. Bogor Agricultural University. Bogor.

[3] Wetter, L.R., F. Constabel. 1991. Metode kultur jaringan tanaman. Badnung Institute of Technology. Bandung.

[4] Paz, T.A., V.A. dos Santos, M.C. Inàcio, E.S. Pina, A.M. Pereira, M. Furlan. 2013. Production of the Quinone-Methide Triterpene Maytenin by In Vitro adventitious roots of Peritassa campestris (Cambess.) A.C.Sm. (Celastraceae) and rapid detection and identification by APCI-ITMS/MS. BioMed Res. Int. 1-7.

[5] Rizzello, F., A. De Paolis, M. Durante, F. Blando, G. Mita, S. Caretto. 2014. Enhanced production of bioactive isoprenoid compounds from cell suspension cultures of Artemisia annua L. Using $\beta$-Cyclodextrins. Int. J. Mol. Sci. 15. 19092-19195.

[6] Yonghong, L., G. Junping, F. Shui-zhang. 2009. High frequency in vitro embryogenic callus induction and plant regeneration from Indiangrass mature caryposis. Scientia Horticulturae. 119. 306-309.

[7] Mucciarelli, M., G. Marisa, S. Silvano, M. Massimo. 1993. Callus induction and plant regeneration in Vetiveria zizanioides. Plant Cell Tissue Organ Cult. 35. 267-271.

[8] Umami, N., A. Ryo, G. Takahiro, I. Genki, T. Hidenori. 2016. Study on callus induction system of 4 genotype of Napiergrass (Pennisetum purpureum). Anim. Prod. 18(3). 131-140.

[9] Kumari, S., R.K. Pandey, K. Uttam. 2015. Invitro callus induction from two different explants stem and leaf in Carthamustinctorius Linn. Eur. J. Exp. Bio. 5(2). 1-4.

[10] Durrani, N.S., D. Ahmad, A. Jalal, H. Rajab, M.S. Khan. 2017. The effect of explant sources and growth regulators on callus induction and regeneration in different tomato cultivars. The J. Anim. Plant Sci. 27(2). 481-489.

[11] Zulkarnain. 2011. Kultur jaringan tanaman. Bumi Aksara. Jakarta.

[12] ElNour, M.E.M., M.A.A. Ammar, \& E.A.T.S. Badr. 2015. Effect of different concentrations of auxins and combination with kinetin on callus initiation of Trigonella Foenum- Graecum. L. Int. J. Technic. Res. Appl. 3(2).117-122.

[13] Akande, S.R., O.B. Morufat, A.O. Benjamin. 2009. Effects of plant growth regulators and explant types on callus formation in African
Yam Bean (Sphenostylis stenocarpa (Hochst. Ex A. Rich) Harms). Kasetsart J. Nat. Sci. 43(3). 442-448.

[14] Savita, V., G.S. Virk, N.I. Avinash. 2010. Effect of explant type and different plant growth regulators on callus induction and plantlet regeneration in Citrus jambhiri Lush. Environ. We Int. J. Sci. Tech. 5. 97-106.

[15] Abd Elaleem, K. G., M.A. Magda, K.M.N. Moawiya. 2015. Effect of Explants and plant growth regulators on callus induction in Ricinus communis L. Res. J. Pharmaceut. Sci. 4(1). 1-6.

[16] Hartman, H.T., D.E. Kester, F.T. Daviz-Jr. 1990. Plant propagation: principles and practices. Englewood Clifts. Prentice-Hall International, Inc. New Jersey.

[17] Pierik, R.L.M. 1997. In Vitro culture of higher plants. Kluwer Academic Publisher, Dordrecht. The Netherlands.

[18] George, E.F. 1993. Plant propagation by tissue culture. Eastern Press. Eversely.

[19] Taiz, L., E. Zeiger. 1991. Plant physiology. Benjamin/Cumings Publishing. Redwood.

[20] Wardani, D.P., Solichatun, S. Ahmad Dwi. 2004. Pertumbuhan dan produksi saponin kultur kalus Talinum paniculatum Gaertn. pada variasi penambahan asam 2,4diklorofenoksi Asetat (2,4-D) dan kinetin. Biofarmasi. 2(1). 35-43.

[21] Amali, P., S.J., Kingsley, \& Ignacimuthu, S. 2014. High frequency callus induction and plant regeneration from shoot tip explants of Sorghum Bicolor L. Moench. Int. J. Pharm. Sci. 6(6). 213-216.

[22] Esyanti, R.R., Iriawati, M. Olga. 2013. Vetiver oil production from root culture of Vetiveria zizanioides. Int. Schol. Sci. Res. Innov. 7(9). 863-866.

[23] Sompornpailin, K., K. Chonnikarn. 2016. Synergistic effects of BAP and Kinetin media additives on regeneration of Vetiver grass (Vetiveria zizanioides L. Nash). Aust. J. Crop Sci. 10(5). 726-731.

[24] Chaudhry, Z., A. Amber, R. Hamid. 2007. Effect of variety and plant growth regulators on callus proliferation and regeneration response of three tomato cultivars (Lycopersicon esculentum). Pak. J. Bot. 39(3). 857-869.

[25] Arivalagan, U., G.A. Peter, N. Arun. 2012. Effect of growth hormones on callus induction of Sauropus androgynous (Sweet Shoot). Ann. Biol. Res. 3(10). 4668-4674. 